\title{
IMMUNOLOGICAL STUDIES ON THE LOCAL INFECTIOUS BURSAL DISEASE VIRUS (IBD) ADAPTED ON SPECIFIC PATHOGEN FREE EMBRYONATED CHICKEN EGGS SPF (ECE)
}

NADIA M. IBRAHIM

Veterinary Serum and Vaccine Research Institute, ARC, Ministry of Agriculture, DOKKIGIZA, EGYPT

(Manuscript received 14 December 2010 )

\begin{abstract}
Local isolate of (IBD) virus [EID $10^{6} / \mathrm{ml}$ ] was propagated for three passages on (SPF) embryonated chicken eggs (EID ${ }_{50}$ $10^{6.5} / \mathrm{ml}$ ) followed by three passages on SPF chickens (EID 50 $10^{8} / \mathrm{ml}$ ), then, for hundred and ten serial passages on SPF embryonated chicken eggs prepared and titrated (EID $10^{7} / \mathrm{ml}$ ) after every 5 passages. The virus was inoculated into 21 days old chickens and observed for 21 days post-infection, then, challenged with virulent IBD virus. Passages $(110,77,55)$ were used for preparation of live attenuated vaccines mild, intermediate, hot (IBDV) vaccines on SPF (ECE), respectively. The evaluation of the prepared vaccines was carried out for sterility, safety and potency. The potency was performed by measuring humoral and cellular immune response, as well as, protection percentage against virulent IBDV.The Efficacy of the prepared vaccine was estimated for up to six months.
\end{abstract}

\section{INTRODUCTION}

Infectious Bursal Disease Virus (IBDV) is of considerable economic interest for poultry industry worldwide.

The vaccine is used for control of the disease which is a common practice in the poultry industry.

However, the use of vaccines, the incidence of IBD virus infection and associated disease problems are still common.

Since 1987, there had been an increasing number of acute cases of IBDV with high mortality even in older chickens, being more evident with highly virulent IBD virus. The highly virulent IBDV has similar antigenicity to the classical strains. It can establish infections at levels of maternal antibodies that were protective against classical strains.

Therefore, there is a great attention to produce IBDV attenuated vaccines from field isolate of IBDV through serial passages in embryonated eggs (Yamaguch et al ., 1996). 
The aim of the present study is propagation and adaptation of IBDV field isolate on $\operatorname{SPF}(E C E)$ for prepartion of live attenuated vaccine and evaluating the efficacy and potency of the vaccine in young susceptiable chickens.

\section{MATERIALS AND METHODS}

1-Virus Strain: IBDV bursal homogenate of local Egyptian isolate with titer of $10^{6}$ (Nadia 2001).

2-Chicks: Four hundreds 21 days old hubbard chickens susceptible to IBD virus were used for vaccine evaluation .

3-Embryos: Embryonated chickens specific pathogen-free (SPF) eggs were obtained from Ministry of Agriculture Koum Osheim, Fayoum, Egypt. At zero days, eggs were kept under observation in the incubator for 9-10 days, and were used for propagation and titration of IBD virus.

4-Media: Nutrient agar, Sabauraoud`s glucose, thioglycolate broth and Frey's media were used for testing sterility of the prepared vaccines.

\section{Methods}

1-Propagation of IBD virus was carried out on SPF (ECE)for three passages, followed by three passages on SPF chiken, then, for hunderd and ten passages with titration of each five passages on SPF (ECE). It was applied according to Jackwood et al. (1984).The infectivity titers EID $_{50} / \mathrm{ml}$ were calculated according to Reed and Maench(1938).

2-Preparation of different types of vaccine. Live attenuated IBD virus on SPF (ECE) was used[the passage 55, p 77, p110] according to Isac et al. (2002).

\section{3-Vaccination of chicks}

a. Each bird was vaccinated with one dose of the live attenuated prepared vaccine [ $10^{5} \mathrm{EID}_{50}$ of each vaccine contained in $0.3 \mathrm{ml}$ physiological saline].

\section{b. Safety test}

Each bird of 21 days old [10 chicks for each group] was installed intraocularly (1/0) with 10 field dose/bird with each prepared vaccine. The chicks were observed for 21 days post-inoculation, and three birds/group were weekly subjected to bursal/ body index and histopathological examination.

4-Challenge test: It was carried out according to Saif-Edin et al . (1996).

The previous vaccines were tested for sterility according to OIE , for immunological effect with serum neutrilization test (Rossiter et al ., 1985), lymphocyte blastogenesis assay( Garn et al ., 1994),bursal body weight ratio (Tasi and Saif, 1992), for histological examination (Nakamura et al ., 1990), for protection and 
keeping quality (Saif-Edin et al ., 1996). These tests were carried out and compared with those vaccinated with (B.vac, D 78,228 E).

\section{RESULTS}

Table 1. Infectivity titers of IBDV isolation on SPF (ECE).

\begin{tabular}{|c|c|}
\hline NO. of passages & Infectivity titer in Log $10\left[\mathrm{EID}_{50} / \mathrm{ML}\right]$ \\
\hline $1^{\text {st }}$ passage & 6.1 \\
\hline $2^{\text {nd }}$ passage & 6.2 \\
\hline $3^{\text {rd }}$ passage & 6.5 \\
\hline
\end{tabular}

Table 2. Infectivity titers of propagated [IBDV] isolation [SPF] young chicks.

\begin{tabular}{|c|c|}
\hline NO. of passages & Infectivity titers in $\log 10\left[\mathrm{EID}_{50} / \mathrm{ml}\right]$ \\
\hline $1^{\mathrm{ST}}$ passage & 7 \\
\hline $2^{\text {nd }}$ passage & 7.5 \\
\hline $3^{\text {rd }}$ passage & 8 \\
\hline
\end{tabular}


Table 3. Propagation and infectivity titers of further propagated IBDV isolate on SPF(ECE).

\begin{tabular}{|c|c|c|c|c|c|c|}
\hline $\begin{array}{l}\text { NO.of } \\
\text { passages }\end{array}$ & $\begin{array}{l}\text { Route of } \\
\text { inoculatin }\end{array}$ & $\begin{array}{l}\text { NO.of } \\
\text { Inoculated } \\
\text { egggs }\end{array}$ & $\begin{array}{l}\text { NO.of } \\
\text { Dead } \\
\text { eggs }\end{array}$ & $\begin{array}{l}\text { NO.of } \\
\text { Postive } \\
\text { eggs }\end{array}$ & $\begin{array}{l}\text { Positive lesions of } \\
\text { Inoculated } \\
\text { ECE[IBDV] }\end{array}$ & $\begin{array}{l}\log 10 \\
\mathrm{EID}_{50} / \mathrm{ml}\end{array}$ \\
\hline 1 & C.A.M & 5 & 5 & 5 & $5 / 5$ & 8 \\
\hline 5 & C.A.M & 5 & 5 & 5 & $5 / 5$ & 8 \\
\hline 10 & C.A.M & 5 & 5 & 5 & $5 / 5$ & 8 \\
\hline 15 & C.A.M & 5 & 5 & 5 & $5 / 5$ & 8 \\
\hline 16 & C.A.S & 5 & 5 & 5 & $5 / 5$ & 8 \\
\hline 20 & C.A.S & 5 & 5 & 5 & $5 / 5$ & 8 \\
\hline 25 & C.A.S & 5 & 5 & 5 & $5 / 5$ & 8 \\
\hline 30 & C.A.S & 5 & 5 & 5 & $5 / 5$ & 8 \\
\hline 34 & C.A.S & 5 & 5 & 5 & $5 / 5$ & 8 \\
\hline 35 & C.A.S & 5 & 4 & 5 & $5 / 5$ & 8 \\
\hline 40 & C.A.S & 5 & 4 & 5 & $5 / 5$ & 8 \\
\hline 45 & C.A.S & 5 & 4 & 5 & $5 / 5$ & 8 \\
\hline 50 & C.A.S & 5 & 4 & 5 & $5 / 5$ & 8 \\
\hline 55 & C.A.S & 5 & 4 & 5 & $5 / 5$ & 8 \\
\hline 60 & C.A.S & 5 & 4 & 5 & $5 / 5$ & 7.75 \\
\hline 64 & C.A.S & 5 & 4 & 5 & $5 / 5$ & 7.75 \\
\hline 65 & C.A.S & 5 & 4 & 5 & $5 / 5$ & 7.50 \\
\hline 68 & C.A.S & 5 & 4 & 5 & $5 / 5$ & 7 \\
\hline 69 & C.A.S & 5 & 1 & 5 & $5 / 5$ & 7 \\
\hline 70 & C.A.S & 5 & 0 & 5 & $5 / 5$ & 7 \\
\hline 75 & & 5 & 0 & 5 & $5 / 5$ & 7 \\
\hline 77 & & 5 & 0 & 5 & $5 / 5$ & 7 \\
\hline 78 & & 5 & 4 & 5 & $5 / 5$ & 7 \\
\hline 79 & & 5 & 4 & 5 & $5 / 5$ & 7 \\
\hline 80 & & 5 & 5 & 5 & $5 / 5$ & 7 \\
\hline 85 & & 5 & 5 & 5 & $5 / 5$ & 7 \\
\hline 90 & & 5 & 5 & 5 & $5 / 5$ & 7 \\
\hline 93 & & 5 & 5 & 5 & $5 / 5$ & 7 \\
\hline 94 & & 5 & 4 & 5 & $5 / 5$ & 7 \\
\hline 95 & & 5 & 4 & 5 & $5 / 5$ & 7 \\
\hline 96 & & 5 & 4 & 5 & $5 / 5$ & 7 \\
\hline 97 & & 5 & 4 & 5 & $5 / 5$ & 7 \\
\hline 98 & & 5 & 3 & 5 & $5 / 5$ & 7 \\
\hline 99 & & 5 & 3 & 5 & $5 / 5$ & 7 \\
\hline 100 & & 5 & 2 & 5 & $5 / 5$ & 7 \\
\hline 105 & & 5 & 2 & 5 & $5 / 5$ & 7 \\
\hline 110 & & 5 & 2 & 5 & $5 / 5$ & 7 \\
\hline
\end{tabular}

C.A.M (Chiroallantoic Membrane).

C.A.S (Chiroallantoic Sac).

Positive lesion of inoculated embryonated eggs with IBDV embryos Subcutaneous oedema , Haemorrhages,Liver necrosis, and Death.Chiroallantouc membrane ,Haemorratgic,Oedematous. 
Table 4. Experimental infection of 21 days old chicks by propagated IBDV isolate on SPF (ECE).

\begin{tabular}{|c|c|c|c|c|c|c|}
\hline $\begin{array}{l}\text { NO.of } \\
\text { passages }\end{array}$ & $\begin{array}{l}\text { Infectivity titer } \\
\text { in } \\
\text { Log } 10 \\
\text { EID } 50 / \mathrm{ml}\end{array}$ & $\begin{array}{l}\text { NO. of } \\
\text { chicks } \\
\text { used }\end{array}$ & $\begin{array}{l}\text { NO. of } \\
\text { dead } \\
\text { chicks }\end{array}$ & $\begin{array}{c}\text { Mortality } \\
\%\end{array}$ & $\begin{array}{l}\text { NO. of } \\
\text { contact } \\
\quad \text { control }\end{array}$ & $\begin{array}{l}\text { NO .of dead } \\
\text { contact } \\
\text { control }\end{array}$ \\
\hline 1 & 8 & 10 & 10 & $100 \%$ & 3 & 3 \\
\hline 5 & 8 & 10 & 10 & $100 \%$ & 3 & 3 \\
\hline 10 & 8 & 10 & 10 & $100 \%$ & 3 & 3 \\
\hline 15 & 8 & 10 & 8 & $80 \%$ & 3 & 3 \\
\hline 20 & 8 & 10 & 8 & $80 \%$ & 3 & 3 \\
\hline 25 & 8 & 10 & 5 & $50 \%$ & 3 & 3 \\
\hline 30 & 8 & 10 & 0 & $0 \%$ & 3 & 0 \\
\hline 35 & 8 & 10 & 4 & $40 \%$ & 3 & 0 \\
\hline 40 & 8 & 10 & 0 & $0 \%$ & 3 & 0 \\
\hline 45 & 8 & 10 & 0 & $0 \%$ & 3 & 0 \\
\hline 50 & 8 & 10 & 2 & $20 \%$ & 3 & 0 \\
\hline 55 & 8 & 10 & 0 & $0 \%$ & 3 & 0 \\
\hline 60 & 7.75 & 10 & 0 & $0 \%$ & 3 & 0 \\
\hline 65 & 7.50 & 10 & 0 & $0 \%$ & 3 & 0 \\
\hline 70 & 7 & 10 & 0 & $0 \%$ & 3 & 0 \\
\hline 75 & 7 & 10 & 0 & $0 \%$ & 3 & 0 \\
\hline 80 & 7 & 10 & 0 & $0 \%$ & 3 & 0 \\
\hline 85 & 7 & 10 & 0 & $0 \%$ & 3 & 0 \\
\hline 90 & 7 & 10 & 0 & $0 \%$ & 3 & 0 \\
\hline 95 & 7 & 10 & 0 & $0 \%$ & 3 & 0 \\
\hline 100 & 7 & 10 & 0 & $0 \%$ & 3 & 0 \\
\hline 110 & 7 & 10 & 0 & $0 \%$ & 3 & 0 \\
\hline
\end{tabular}


Table 5. The challenge of chicks inoculated with the propagated IBDV isolate on SPF (ECE).

\begin{tabular}{|c|c|c|c|c|c|c|c|}
\hline $\begin{array}{l}\text { NO. of } \\
\text { passages }\end{array}$ & $\begin{array}{c}\text { NO.of inoculated } \\
\text { chicks with virulent } \\
\text { virus }\end{array}$ & $\begin{array}{c}\text { NO. } \\
\text { dead } \\
\text { chicks }\end{array}$ & $\begin{array}{c}\text { Morbidity } \\
\%\end{array}$ & $\begin{array}{c}\text { Mortality } \\
\%\end{array}$ & P/M lesions & $\begin{array}{c}\text { NO.of } \\
\text { Challenge } \\
\text { control } \\
\end{array}$ & $\begin{array}{c}\text { NO. of dead } \\
\text { challenge } \\
\text { control } \\
\end{array}$ \\
\hline 15 & 2 & 0 & 0 & 0 & Not found & 3 & 3 \\
\hline 20 & 2 & 0 & 0 & 0 & Not found & 3 & 3 \\
\hline 25 & 5 & 0 & 0 & 0 & Not found & 3 & 3 \\
\hline 30 & 6 & 2 & 33 & 33 & $\begin{array}{l}\text { Typical } \\
\text { IBDV } \\
\text { lesions }\end{array}$ & 3 & 3 \\
\hline 35 & 10 & 2 & 33 & 33 & $\begin{array}{l}\text { Typical } \\
\text { IBDV } \\
\text { lesions }\end{array}$ & 3 & 3 \\
\hline 40 & 10 & 0 & 0 & 0 & Not found & 3 & 3 \\
\hline 45 & 10 & 0 & 0 & 0 & Not found & 3 & 3 \\
\hline 50 & 8 & 2 & 25 & 25 & $\begin{array}{l}\text { Typical } \\
\text { IBDV } \\
\text { lesions }\end{array}$ & 3 & 3 \\
\hline 55 & 10 & 0 & 0 & 0 & Not found & 3 & 3 \\
\hline 60 & 10 & 0 & 0 & 0 & Not found & 3 & 3 \\
\hline 65 & 10 & 0 & 0 & 0 & Not found & 3 & 3 \\
\hline 70 & 10 & 0 & 0 & 0 & Not found & 3 & 3 \\
\hline 75 & 10 & 0 & 0 & 0 & Not found & 3 & 3 \\
\hline 80 & 10 & 0 & 0 & 0 & Not found & 3 & 3 \\
\hline 85 & 10 & 0 & 0 & 0 & Not found & 3 & 3 \\
\hline 90 & 10 & 0 & 0 & 0 & Not found & 3 & 3 \\
\hline 95 & 10 & 0 & 0 & 0 & Not found & 3 & 3 \\
\hline 100 & 10 & 0 & 0 & 0 & Not found & 3 & 3 \\
\hline 110 & 10 & 0 & 0 & 0 & Not found & 3 & 3 \\
\hline
\end{tabular}


Table 6. Experirnental infection of chicks inoculated with propagated IBDV isolate on SPF (ECE) and their challenge.

\begin{tabular}{|c|c|c|c|c|c|c|c|c|c|c|c|c|c|}
\hline $\begin{array}{c}\text { NO. of } \\
\text { passages }\end{array}$ & $\begin{array}{l}\text { Infectivity } \\
\text { titer in } \\
\text { Log10, } \\
\text { EID50/ml }\end{array}$ & $\begin{array}{c}\text { NO.of } \\
\text { Chicks } \\
\text { used }\end{array}$ & $\begin{array}{l}\text { NO. of } \\
\text { Dead } \\
\text { chicks }\end{array}$ & Mortality & $\begin{array}{l}\text { NO.of } \\
\text { Contact } \\
\text { control }\end{array}$ & $\begin{array}{l}\text { NO.of } \\
\text { dead } \\
\text { Contact } \\
\text { control }\end{array}$ & $\begin{array}{c}\text { NO. of } \\
\text { Inoculated } \\
\text { Chicks with } \\
\text { Virulent virus }\end{array}$ & $\begin{array}{l}\text { NO.of } \\
\text { Dead } \\
\text { chicks }\end{array}$ & Morbidity & Mortality & $\begin{array}{l}\mathrm{P} / \mathrm{M} \\
\text { lesions }\end{array}$ & $\begin{array}{c}\text { NO.of } \\
\text { Challenge } \\
\text { control }\end{array}$ & $\begin{array}{c}\text { NO. of } \\
\text { dead } \\
\text { Challenge } \\
\text { control }\end{array}$ \\
\hline P50 & 8 & 10 & 2 & $20 \%$ & 3 & 0 & 8 & 2 & $25 \%$ & $25 \%$ & $\begin{array}{l}\text { IBDV } \\
\text { lesion }\end{array}$ & 3 & 3 \\
\hline P51 & 8 & 10 & 2 & $20 \%$ & 3 & 0 & 8 & 2 & $25 \%$ & $25 \%$ & $\begin{array}{l}\text { IBDV } \\
\text { lesion }\end{array}$ & 3 & 3 \\
\hline P52 & 8 & 10 & 2 & $20 \%$ & 3 & 0 & 8 & 2 & $25 \%$ & $25 \%$ & $\begin{array}{l}\text { IBDV } \\
\text { lesion }\end{array}$ & 3 & 3 \\
\hline P53 & 8 & 10 & 0 & 0 & 3 & 0 & 10 & 0 & 0 & 0 & $\begin{array}{c}\text { Not } \\
\text { found }\end{array}$ & 3 & 3 \\
\hline P54 & 8 & 10 & 0 & 0 & 3 & 0 & 10 & 0 & 0 & 0 & $\begin{array}{c}\text { Not } \\
\text { found }\end{array}$ & 3 & 3 \\
\hline P55 & 8 & 10 & 0 & 0 & 3 & 0 & 10 & 0 & 0 & 0 & $\begin{array}{c}\text { Not } \\
\text { found }\end{array}$ & 3 & 3 \\
\hline
\end{tabular}


Table 7. Safety test.

\begin{tabular}{|c|c|c|c|c|c|c|c|}
\hline \multirow[b]{2}{*}{$\begin{array}{l}\text { Group of } \\
\text { vaccination }\end{array}$} & \multirow{2}{*}{$\begin{array}{l}\text { NO.of } \\
\text { chicks } \\
\text { used }\end{array}$} & \multicolumn{3}{|c|}{$\begin{array}{c}\text { Vaccination| chick 10fild close } \\
\text { W.P.V }\end{array}$} & \multicolumn{3}{|c|}{ W.p.challanged } \\
\hline & & $\begin{array}{l}1^{S T} \\
\text { Morb. } \\
\text { morta }\end{array}$ & $\begin{array}{c}2^{\text {nd }} \\
\text { Morb. } \\
\text { morta }\end{array}$ & $\begin{array}{l}\text { 3rd } \\
\text { Morb. } \\
\text { morta }\end{array}$ & $\begin{array}{c}1^{\mathrm{ST}} \\
\text { Morb. } \\
\text { morta }\end{array}$ & $\begin{array}{c}2^{\text {nd }} \\
\text { Morb. } \\
\text { morta }\end{array}$ & $\begin{array}{c}\text { 3rd } \\
\text { Morb. } \\
\text { morta }\end{array}$ \\
\hline P55 & 10 & $\begin{array}{l}0 \\
0 \\
\end{array}$ & $\begin{array}{l}0 \\
0 \\
\end{array}$ & $\begin{array}{l}0 \\
0 \\
\end{array}$ & $\begin{array}{l}0 \\
0 \\
\end{array}$ & $\begin{array}{l}0 \\
0 \\
\end{array}$ & $\begin{array}{l}0 \\
0 \\
\end{array}$ \\
\hline P77 & 10 & $\begin{array}{l}0 \\
0 \\
\end{array}$ & $\begin{array}{l}0 \\
0 \\
\end{array}$ & $\begin{array}{l}0 \\
0 \\
\end{array}$ & $\begin{array}{l}0 \\
0 \\
\end{array}$ & $\begin{array}{l}0 \\
0 \\
\end{array}$ & $\begin{array}{l}0 \\
0 \\
\end{array}$ \\
\hline P110 & 10 & $\begin{array}{l}0 \\
0 \\
\end{array}$ & $\begin{array}{l}0 \\
0\end{array}$ & $\begin{array}{l}0 \\
0 \\
\end{array}$ & $\begin{array}{l}0 \\
0 \\
\end{array}$ & $\begin{array}{l}0 \\
0 \\
\end{array}$ & $\begin{array}{l}0 \\
0 \\
\end{array}$ \\
\hline control & 10 & $\begin{array}{l}0 \\
0\end{array}$ & $\begin{array}{l}0 \\
0\end{array}$ & $\begin{array}{l}0 \\
0\end{array}$ & $\begin{array}{l}6 \\
6\end{array}$ & $\begin{array}{l}4 \\
4\end{array}$ & $\begin{array}{l}-- \\
--\end{array}$ \\
\hline
\end{tabular}

W.P.V =WEAK POST VACCINATION

W.P.CHALLANGED =WEAK POST CHALLENGED

MORB. $=$ MORBIDITY

MORTA. =MORTALITY

Table 8. Sterility of prepared live attenuated IBDV.

\begin{tabular}{|c|c|c|c|}
\hline \multirow{2}{*}{ media } & \multicolumn{3}{|c|}{ Live propagated IBDV } \\
\cline { 2 - 4 } & P55 & P77 & P110 \\
\hline Nutrient ager & NC & NC & NC \\
\hline Thioglycollate broth & NT & NT & NT \\
\hline Saboraud glucose agar & NC & NC \\
\hline Frey's media & NC & NC & NC \\
\hline
\end{tabular}

NC $=$ NO COLONIES ON THE USED MEDIUM

NT $=$ NO TURBIDITY IN USED BROTH 
Table 9. Mean neutralizing anti- body titers $\log _{2}$ in sera of chicks vaccinated with locally prepared live attenuated vaccine SPF (ECE) compared with those vaccinated with B.vac, D78 and 228E.

\begin{tabular}{|c|c|c|c|c|c|c|c|c|c|c|c|c|c|c|c|c|c|c|c|c|c|}
\hline \multirow{2}{*}{$\begin{array}{l}\text { Chicken } \\
\text { group }\end{array}$} & \multirow{2}{*}{$\begin{array}{c}\text { Type of } \\
\text { Vaccine } \\
\text { used }\end{array}$} & \multicolumn{20}{|c|}{ Week post-vaccination } \\
\hline & & 1 & 2 & 3 & 4 & 5 & 6 & 7 & 8 & 9 & 10 & 11 & 12 & 13 & 14 & 15 & 16 & 18 & 20 & 22 & 24 \\
\hline 1 & Live SPF (ECE) (p55) & 5 & 6 & 7 & 7 & 7 & 8 & 8 & 8 & 7 & 7 & 7 & 6 & 6 & 6 & 5 & 5 & 5 & 4 & 4 & 4 \\
\hline 2 & Live SPF (ECE) (p77) & 5 & 5 & 7 & 7 & 8 & 8 & 9 & 9 & 10 & 10 & 9 & 8 & 8 & 7 & 5 & 5 & 4 & 4 & 4 & 3 \\
\hline 3 & Live SPF (ECE) (p110) & 6 & 7 & 8 & 8 & 12 & 11 & 11 & 12 & 12 & 12 & 12 & 12 & 12 & 11 & 11 & 10 & 10 & 10 & 9 & 9 \\
\hline 4 & $\begin{array}{c}\text { Mild } \\
\text { (B.vac) }\end{array}$ & 4 & 5 & 6 & 7 & 8 & 8 & 11 & 10 & 10 & 9 & 9 & 8 & 8 & 7 & 5 & 5 & 4 & 4 & 4 & 3 \\
\hline 5 & $\begin{array}{c}\text { Intermediate } \\
\text { (D78) }\end{array}$ & 5 & 5 & 7 & 8 & 7 & 8 & 10 & 9 & 9 & 9 & 8 & 7 & 6 & 6 & 5 & 4 & 4 & 3 & 3 & 3 \\
\hline 6 & $\begin{array}{c}\text { Hot } \\
(228 \mathrm{E}) \\
\end{array}$ & 5 & 6 & 7 & 7 & 7 & 7 & 8 & 8 & 8 & 8 & 7 & 7 & 6 & 5 & 4 & 4 & 4 & 3 & 3 & 3 \\
\hline 7 & control & 0 & 0 & 0 & 0 & 0 & 0 & 0 & 0 & 0 & 0 & 0 & 0 & 0 & 0 & 0 & 0 & 0 & 0 & 0 & 0 \\
\hline
\end{tabular}


Table 10. Mean of lymphocyte blastogenesis of vaccinated chicks with locally prepared live attenuated vaccines on $\operatorname{SPF}(E C E)$ compared with those vaccinated with B.vac,D78 and 228E.

\begin{tabular}{|c|c|c|c|c|}
\hline \multirow{2}{*}{ Chicken group } & \multirow{2}{*}{ Type of vaccine used } & \multicolumn{3}{|c|}{ Weeks after vaccination } \\
\cline { 3 - 5 } & Live SPF (ECE) P55 & 0.489 & 0.366 & 0.290 \\
\hline \multirow{2}{*}{1} & Live SPF (ECE) P77 & 0.429 & 0.338 & 0.320 \\
\cline { 2 - 5 } & Live SPF (ECE) P110 & 0.442 & 0.266 & 0.590 \\
\hline 2 & Mild B.vac & 0.402 & 0.302 & 0.400 \\
\hline 3 & Intermediate D78 & 0.443 & 0.330 & 0.275 \\
\hline 4 & Hot 228E & 0.515 & 0.345 & 0.235 \\
\hline 5 & control & 0.04 & 0.01 & 0.03 \\
\hline
\end{tabular}

Table 11. Bursal body weight ratio in vaccinated chickens before and after challenge.

\begin{tabular}{|c|c|c|c|c|c|c|c|}
\hline \multirow[b]{2}{*}{$\begin{array}{c}\text { Chicken } \\
\text { group }\end{array}$} & \multirow[b]{2}{*}{$\begin{array}{l}\text { Type of } \\
\text { vaccine } \\
\text { used }\end{array}$} & \multicolumn{2}{|c|}{ Weight in bursal } & \multicolumn{2}{|c|}{ Body weight } & \multicolumn{2}{|c|}{ Bursal body weight ratio } \\
\hline & & $\begin{array}{c}5 \text { days } \\
\text { post } \\
\text { vaccination }\end{array}$ & $\begin{array}{c}5 \text { days } \\
\text { post } \\
\text { challenge }\end{array}$ & $\begin{array}{c}5 \text { days } \\
\text { post } \\
\text { vaccination }\end{array}$ & $\begin{array}{c}5 \text { days } \\
\text { post } \\
\text { challenge }\end{array}$ & $\begin{array}{c}5 \text { days } \\
\text { post } \\
\text { vaccination }\end{array}$ & $\begin{array}{c}5 \text { days } \\
\text { post } \\
\text { challenge }\end{array}$ \\
\hline 1 & $\begin{array}{l}\text { Live SPF } \\
\text { (ECE) P55 }\end{array}$ & 0.2000 & 0.4021 & 180 & 220 & 1.111 & 1.8277 \\
\hline 2 & $\begin{array}{l}\text { Live SPF } \\
\text { (ECE) P77 }\end{array}$ & 0.1800 & 0.3390 & 190 & 240 & 0.9478 & 1.4125 \\
\hline 3 & $\begin{array}{c}\text { Live SPF } \\
\text { (ECE) } \\
\text { P110 }\end{array}$ & 0.1130 & 0.3260 & 190 & 250 & 0.5947 & 1.3040 \\
\hline 4 & Mild B.vac & 0.09120 & 0.2650 & 170 & 220 & 0.5362 & 1.2045 \\
\hline 5 & D78 & 0.1900 & 0.3420 & 170 & 230 & 1.109 & 1.4089 \\
\hline 6 & $228 \mathrm{E}$ & 0.2100 & 0.3521 & 180 & 220 & 1.1744 & 1.6000 \\
\hline 7 & CONTROL & 0.2030 & 0.3600 & 190 & 250 & 1.0711 & 1.4400 \\
\hline
\end{tabular}


Table 12 .The rate of protection of locally prepared live attenuated IBDV vaccine after preservation at $-20^{\circ} \mathrm{C}$.

\begin{tabular}{|c|c|c|c|c|c|c|c|c|c|c|c|c|c|c|}
\hline \multirow{3}{*}{$\begin{array}{l}\text { Chicken } \\
\text { group }\end{array}$} & \multirow{3}{*}{$\begin{array}{c}\text { Type of } \\
\text { vaccine used }\end{array}$} & \multirow{3}{*}{$\begin{array}{l}\text { Temp. of } \\
\text { Storage }\end{array}$} & \multicolumn{12}{|c|}{ Protection for every month after preservation } \\
\hline & & & \multicolumn{2}{|c|}{$1^{\text {st }}$ month } & \multicolumn{2}{|c|}{$2^{\text {nd }}$ month } & \multicolumn{2}{|c|}{$3^{\text {rd }}$ month } & \multicolumn{2}{|c|}{$4^{\text {th }}$ month } & \multicolumn{2}{|c|}{$5^{\text {th }}$ month } & \multicolumn{2}{|c|}{$6^{\text {th }}$ month } \\
\hline & & & Prot & $\begin{array}{c}\text { Prot. } \\
\%\end{array}$ & Prot. & $\begin{array}{c}\text { Prot. } \\
\% \\
\end{array}$ & Prot. & Prot.\% & Prot. & Prot.\% & Prot. & $\begin{array}{c}\text { Prot. } \\
\%\end{array}$ & Prot. & Prot.\% \\
\hline 1 & $\begin{array}{c}\text { Live } \\
\text { Prepared } \\
\text { P55 }\end{array}$ & $-20^{\circ} \mathrm{C}$ & $5 / 5$ & 100 & $5 / 5$ & 100 & $5 / 5$ & 100 & $5 / 5$ & 100 & $5 / 5$ & 100 & $5 / 5$ & 100 \\
\hline 2 & $\begin{array}{c}\text { Live } \\
\text { Prepared } \\
\text { P77 }\end{array}$ & $-20^{\circ} \mathrm{C}$ & $5 / 5$ & 100 & $5 / 5$ & 100 & $5 / 5$ & 100 & $5 / 5$ & 100 & $5 / 5$ & 100 & $5 / 5$ & 100 \\
\hline 3 & $\begin{array}{c}\text { Live } \\
\text { Prepared } \\
\text { P110 } \\
\end{array}$ & $-20^{\circ} \mathrm{C}$ & $5 / 5$ & 100 & $5 / 5$ & 100 & $5 / 5$ & 100 & $5 / 5$ & 100 & $5 / 5$ & 100 & $5 / 5$ & 100 \\
\hline 4 & control & ----- & $0 / 2$ & 0 & $0 / 2$ & 0 & $0 / 2$ & 0 & $0 / 2$ & 0 & $0 / 2$ & 0 & $0 / 2$ & 0 \\
\hline
\end{tabular}




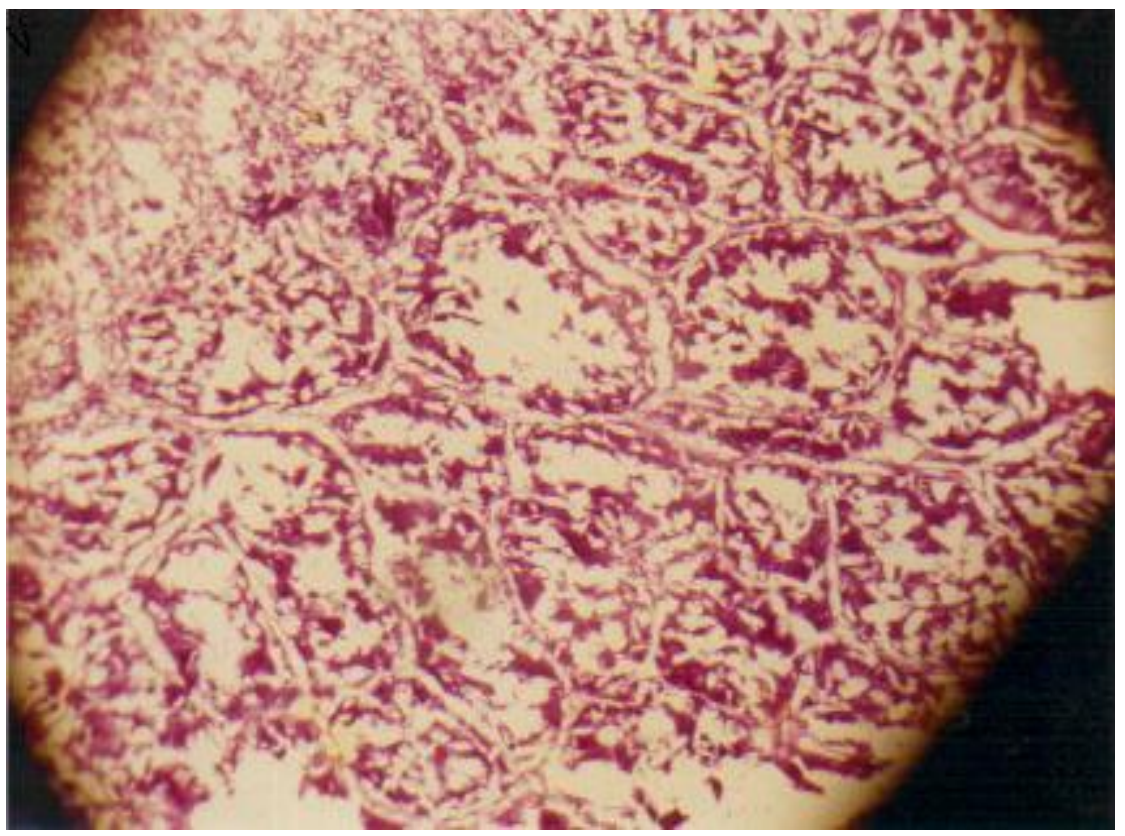

Fig 1. Histopathological section of the bursa of chicken 5 days post vaccination with locally prepared live attenuated IBDV vaccine on SPF ECE P55(X 100).

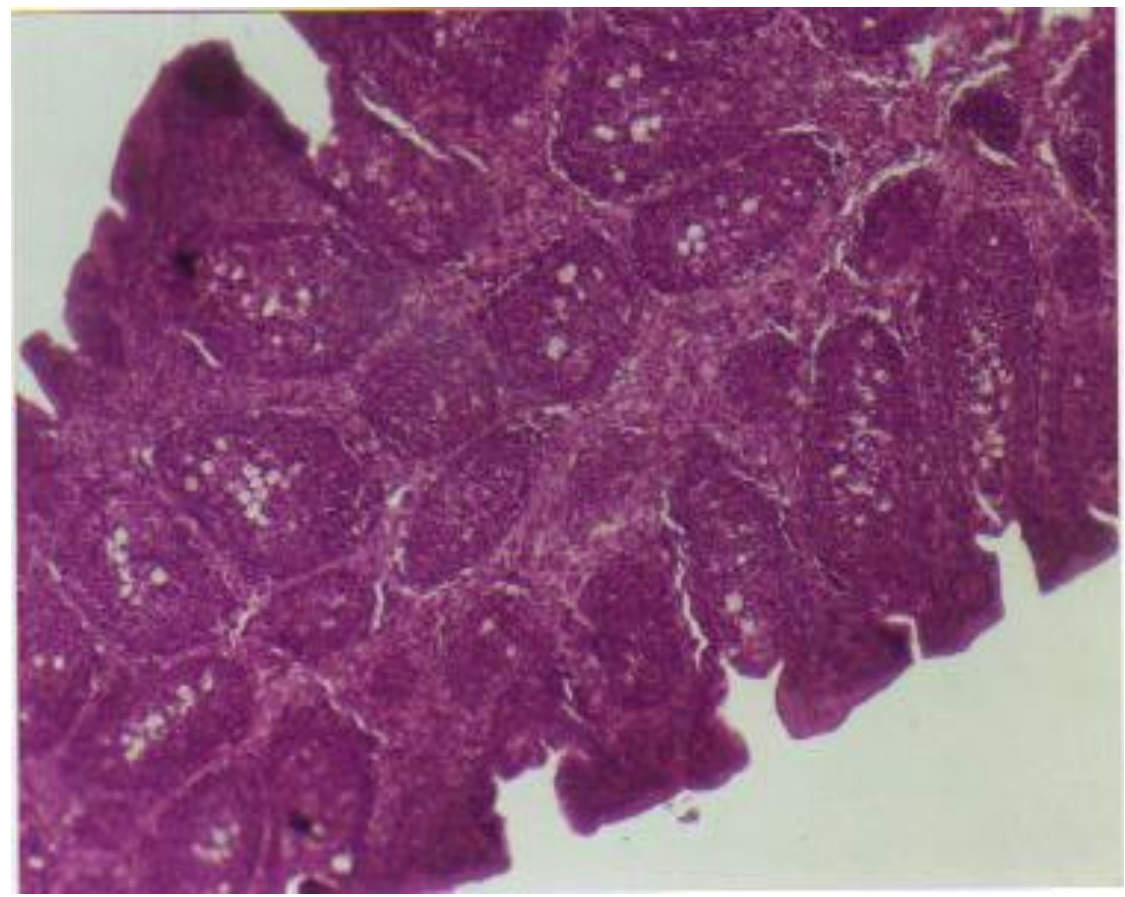

Fig 2. Histopathological section of the bursa of chicken 5 days post-vaccination with locally prepared live attenuated IBDV vaccine on SPF ECE P77 (X 100). 


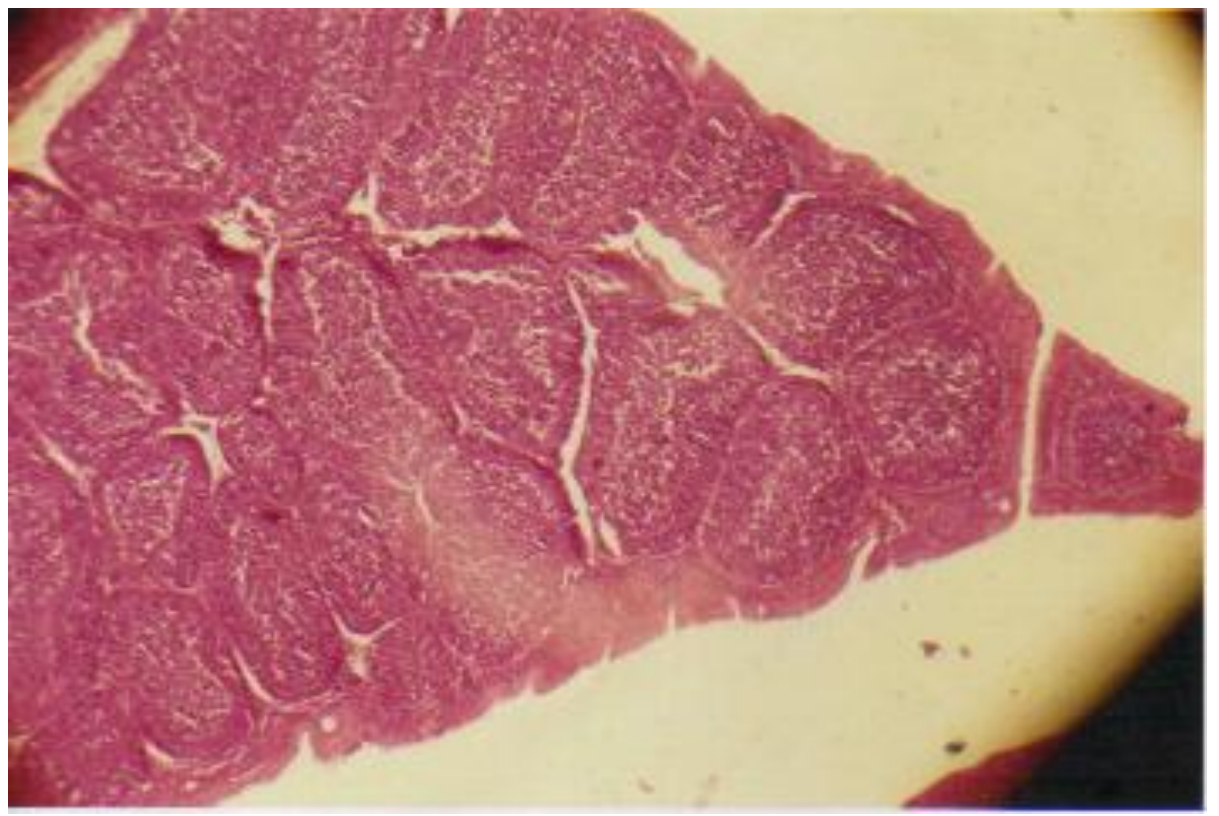

Fig 3. Histopathological section of the bursa of chicken 5days post-vaccination with 1ocal1y prepared live attenuated IBDV vaccine on SPF ECE P110 (X I00).

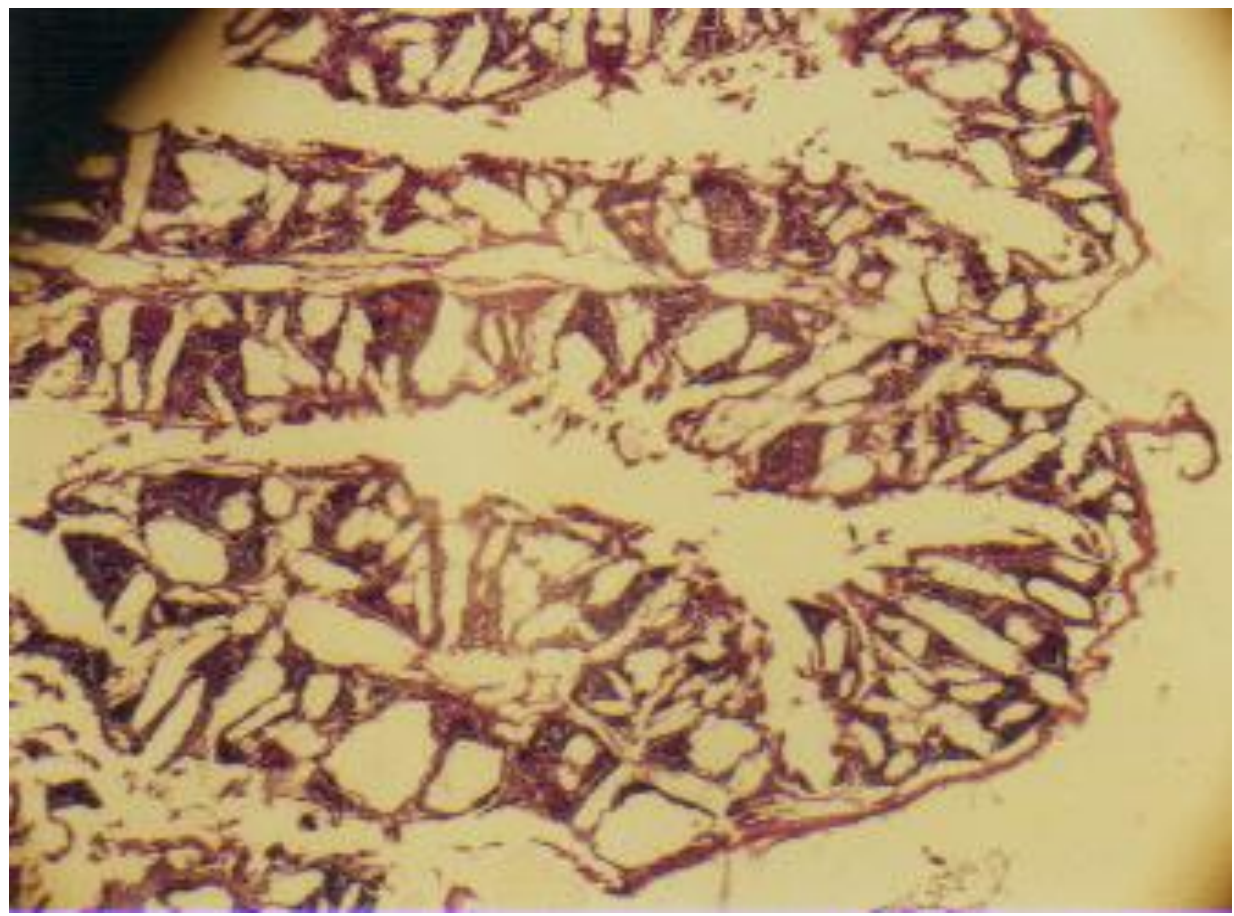

Fig 4. Histopathological section of the bursa of chicken challenged with IBDV 5 days post-experimental infection (X 100). 


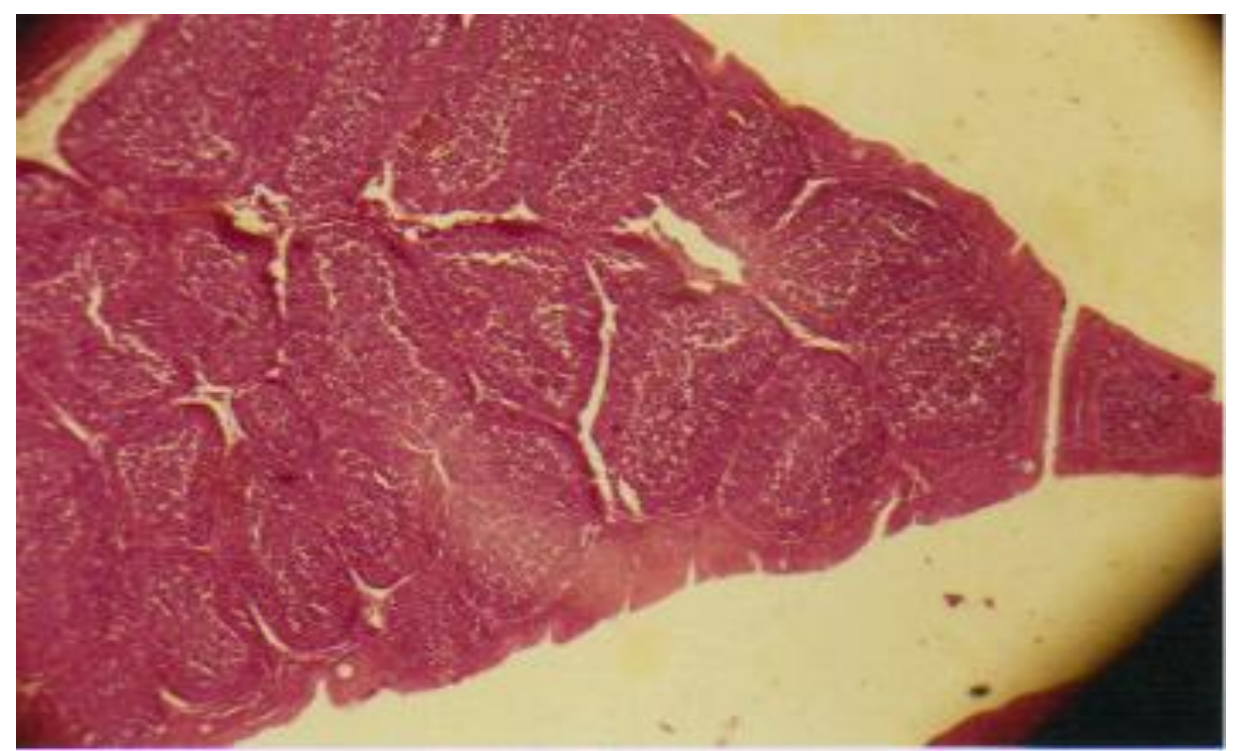

Fig 5. Histopathological section of the bursa of chicken non-vaccinated as control negative (X100).

\section{DISCUSSION}

The aim of present study was to prepare a safe and potent live attenuated IBD vaccine propagated on SPF (ECE) from local field isolate.

The scheme used for preparing the vaccine started with the propagation of a bursal hemogenate of the isolated IBD virus for three passages on SPF embryonated chicken eggs SPF (ECE), followed by further 3 passages on SPF chickens and followed by 110 serial passages on SPF (ECE).

It was noticed in Table 1, that there was an increase in infectivity titer EID $_{50}$ from the first to the third passage with $0.4 \log 10$, while, in Table 2,there was an increase in infectivity titer $\left(\mathrm{EID}_{50}\right)$ from first passage in chicken to third passage with one log, and reached to $10^{8} \mathrm{EID}_{50} / \mathrm{ml}$. This result agreed with that obtained by Dutko et al. (1988).

In Table 3, it was noticed that infectivity titer $\operatorname{EID}_{50} / \mathrm{ml}$ from $p_{1}$ till $p_{59}$ was $10^{8}$, while, p60 till p64 EID 50 decreased and reached to $10^{7.75}$ and p65 till $\mathrm{p}_{69} \mathrm{EID}_{50}$, then, reached $10^{7.50}$ and from p70 till p110 EID 50 it was stable $10^{7}$.

In inoculated eggs from $\mathrm{p} 1$ till $\mathrm{p} 15$, inoculation of SPF (ECE) through chorio allantioc membrane and from p16 till p110 inoculation of SPF (ECE) through chorio allantioc sac and from p1 till p34, the number of dead inoculated embryonated eggs was $5(5 / 5)$ to each passage .Also, we noticed that the mortality rate of inoculated embryos was changed with passages p35 till p68, the number of dead embrys in inoculated eggs with IBDV was $4(4 / 5)$ to each passage and p69 the number of dead 
inoculated eggs $1(1 / 5)$ and from p70till p77 no deaths in inoculated eggs were noticed .

In p78, the number of dead inoculated eggs was $4(4 / 5)$, and in p80 till p93 the number of dead inoculated eggs was 5 (5/5), and from p94 till p97, dead inoculated eggs were $4(4 / 5)$, and in p 98 -p99 the number of dead inoculated eggs was 3 $(3 / 5)$, and from p100 till p110 the number of dead inoculated eggs was $2(2 / 5)$ to each passage. Positive lesion of IBDV in inoculated embryonated eggs was from $\mathrm{p} 1$ to p110. The positive lesion of inoculated eggs with IBDV was as follows:

Embryos $\rightarrow$ edematous, haemorrhagic, liver necrosis and death.

Chorioallantoic membrane $\rightarrow$ edematous, haemorrhagic. The results agreed with those obtained with RAO et al. (1978).

In Table 4, when IBDV was propagated on SPF (ECE) for 110 passages and every five passage, it was inoculated in 10 susceptible 21 days old chicks. The morbidity and mortality rates varied: p1, p5 and p10 of (IBDV) isolate induced $100 \%$ mortalities, p15 and p20 induced 80\%mortalities, P25 of IBDV isolate induced $50 \%$ mortalities, but p30 did not induce any mortality. In p35 it induced $40 \%$ mortalities, in p40 and p45 it did not induce any mortalities, and p50 induced 20\% mortalities.

From $\mathrm{p} 55$ to $\mathrm{p} 110$, no mortalities were observed, and also the contact control chicken from p1 to p25 induced $100 \%$ mortality, but, from p30 to p110 contact control chicken did not induce any mortality, then variation in mortality rates by passages from $p 1$ to $p 50$ but not by passages after that ( $p 55-p 110)$. This may be due to the variation in the epitopes of virulence being altered by further passages. These results are in agreement with those obtained by Michael et al. 1997, Rinaldi (1972) who reported that the IBDV lost its virulence by progressive propagation on SPF (ECE).

In Table 5, when inoculated chicks were challenged with the very virulent IBDV 21days post- inoculation with the prepared passages, the p15-p20-p25did not induce any mortality, but, in p30\&p35 it induced 33\% mortalities, while, in p40\&p45 it did not induce any mortality, but, in p50 it induced $25 \%$ mortalities, in p50 to p110 it did not induce any mortality in chickens.

The prepared passage 55 on SPF (ECE) gave good protection to inoculated chickens. These results agreed with those obtained by Saif (1994).

In Table 6, the passage of choice that did not induce any mortality was which we used p50 to p55 for determining the most safe passage that did not induce any morbidity or no mortalities when inoculated in susceptible chicks. The p50-p51-p52 induced $20 \%$ mortalities and after challenge, it induced $25 \%$ mortalities, but, from 
p53-p54-p55 it did not induce any mortality from inoculated passages or after inoculation with virulent virus.

Passage of choice which did not induce any mortality was p53 which gave $100 \%$ protection. This result agreed with that obtained by Chowd Hury et al., (1996).

In Table 7, it was indicated that the prepared vaccines were safe when inoculated in susceptible chicks with ten times the field dose. It was noticed that there was no morbidity or mortalities in vaccinated chicks, while, all non -vaccinated control died after challenge .This result agreed with that obtained by Saif-Edine et al. (1996).

Table 8 confirms the sterility of prepared vaccines from any contaminant.

From results of Tables 3,4,5,6, we noticed that the passage of choice was p53 $\mathrm{EID}_{50} / \mathrm{ml} 8 \log 10$, and the number of positive eggs [5] was $5 / 5$ and number of dead inoculated eggs was $4[4 / 5]$. In passages 70 to $p 77$, the presence of other variation in infectivity titer $\operatorname{EID}_{50} 7 \log 10$ and number of positive lesion of inoculated eggs [5] 5/5 and number of dead inoculated (ECE ) Zero [0/5] meant an increase in amount of collected eggs from inoculated embryonated eggs.

So, it is profitable to use p77 to inoculated chicks and to determine immune response in inoculated susceptible chicks. We made comparison between three passages 55-77-110 after inoculation in susceptible chicks, and determined immune response (humoral and cellular) compared with other commercial vaccines.

In Table 9, we mentioned the mean neutralizing antibody titers log 2 in sera of vaccinated chicks with the locally prepared vaccine [p110] which induced good humoral immune response from the first week post-vaccination till the $24^{\text {th }}$ week pv[6\&9 log, respectively]and reached to maximum value in week 5 till week 13 (12log2). From week $14-15$ it reached to $11 \log 2$ and in week 16 to 20 it reached to $10 \log 2$ and ended in week 24 (9log2).

In p77, the mean neutralizing antibody titers log2 reached from week (3) to 7log 2 and increased gradually till it reached to the maximum in week 9-10, then, reached $10 \log 2$, then, decreased to gradually till reached to $3 \log 2$ in week 24 , while, in p55 mean neutralizing antibody titers log2 in sera of vaccinated chicks. We noticed that, from the first week, it reached $5 \log 2$ gradually and increased till reached to maximum value in week $6-7-8(8 \log 2)$ and gradually decreased till it reached in week24 (4 $\log 2)$.When compared with other commercial vaccines, we found that mild vaccine (B.vac) vaccine began with $4 \log 2$ in first week and gradually increased till reached to maximum in week $711 \log 2$ and ended with $3 \log 2$ in week 24 . Also, in intermediate vaccine (D78), it began with $5 \log 2$ in first week and gradually increased till reached to maximum in week $7(10 \log 2)$, then, gradually decreased till reached to $3 \log 2$ in week 24 . The hot strain (228E) being the neutralizing antibody titers, began 
from first week with $5 \log 2$ and reached to maximum in week 7 till 11 (8log2) then, decreased till reached $3 \log 2$ in week 24.

From the above results, we noticed that the mild vaccine was highly immunogenic as it induced high neutralizing antibody titers for about 6 months with $9 \log 2 \mathrm{VN}$ antibodies, and the lowest VN antibody titers were induced by intermediate and hot vaccines due to the highly destructive effect of B-CELLS by both vaccines (hot and intermediate).

These results agreed with those obtained by Lukert (1992). So, we recommend to use live mild vaccine in young age susceptible chicks.

In Table10,we noticed that lymphocyte blastogenesis of locally prepared vaccine activated lymphocyte blastogenesis, as it produced high values in first week post- vaccination in p110 (0.442)and still till $3^{\text {rd }}(0.590)$,but, in p77 in first week $(0.425)$ and to $3^{\text {rd }}(0.320)$ and in p55 in first week (0.489)and to $3^{\text {rd }}(290)$ and in mild B.V ac vaccine in first week (0.402) and in third week (0.400) and in D78 first week (0.443) and $3^{\text {rd }}(0-275)$.

In $228 \mathrm{E}$ first week $(0.515)$, 3rd (0.295) these results agreed with those obtained by Mayahi (1997).

The histopathological examination of bursae of vaccinated chickens with the SPF (ECE) revealed that the prepared vaccine from ( $p 110$ ) is of mild type because it did not induce any destructive effect in bursal B-lymphocyte follicles of bursal atrophy.

The prepared vaccine from ( $p 77)$ is of intermediate type because it induced slight destructive effect on Bursal B-lymphocytes of follicles in chickens with low or without maternal antibodies, but, the prepared vaccine from p55 is of hot type because it induced destructive effect in bursal B-lymphocyte follicles in vaccinated chickens. These results agreed with those obtained by Tsukamoto et al. (1995).

From Table11, it is clear that the locally prepared live attenuated vaccines have no clear difference between the bursal body weight ratios of vaccinated chicks and control chicks.

In vaccinated chicks with locally prepared IBDV p110-p77 and p55, we found that the result of bursal body weight ratio after 5 days of vaccination challenged the first one nearly to mild vaccine (B.vac), but the second one challenged nearly to intermediate vaccine (D78) and the third challenged nearly to hot vaccine (228E).

This result agreed with that obtained by Nieper and Muller ( 1994). From these results and from histopatological examination of bursae of vaccinated chickens and also, results of lymphocytes blasogensis, we could classify IBDV propagated on SPF (ECE) as p110 (Mild vaccine), p77 (intermediate vaccine) and p55 (hot vaccine). 
In Table 12, discussing the keeping quality of the prepared live IBD virus vaccines when stored at $-20^{\circ} \mathrm{C}$, it was clear that the vaccines were stable and potent for a period of 6 months where the protection reached $100 \%$.This result agreed with Saif -Edin et al. (1996).

From these results, it could be concluded that adapted locally prepared vaccine on SPF (ECE) P110can be used safely in chickens which have not or of low maternal antibodies [one day old chicks, 3 week old chicks] .So, the preparation of live attenuated vaccine is safe, potent and immunogenic in young chicks.

P77, P55 can be used safely in older chickens at 45 days, but p55 can be used as inactivated vaccine. 


\section{REFERENCES}

1. Chowdhury, E.H., M.R. Islam, P.M. Das, M.L. Dewan and M.S.R. Khan. 1996. Acute infectious bursal disease in chickens: pathological observation and virus isolation. Asian-Australian J. Anim.Sci., 9:465-469.

2. Dutko,Y.S., G.P. Fedorov and V.A. Balabanov. 1988. The course of experimentally induced infectious bursal disease in broiler chicks. Veterinariya Moscow, USSR, 9: 34-36.

3. Garn, H., H. Krause, V. Enmann and K. Drobler. 1994. An improved MTT assay using electron coupling agent menadion. J.Immunol.Meth., 168: 253-256.

4. Isac, R. Rodriguez-Chavez, K. Rosenberger John and S.Cloud Sandra. 2002. haracterization of the antigenic, immunogenic and pathogenic variation of infectious bursal disease virus due to propagation in different host systems [bursa, embryo and cell culture]. 1 _antigenicity and immuilogenicity. Avi. Path., 31: 46371.

5. Jackwood, D.J., Y.M. Saif and J. H. Hnghes. I984. Nucleic acid and structural proteins of infectious bursal diseased virus isolates belonging to serotype I and II.Avi. Dis., 28: 990- 1006.

6. Luckert, P.D. 1992.Infectious bursal disease in veterinary diagnostic virology. Practitioner's guide Edited by Castro,A.E. and Henschele,W .P. Mosby Year Book, St. Ballimore, Boston, Chicago, London.

7. Mayahi,M. 1997.Effect of infectious bursal disease on the cell mediated immunity of chickens to S. Virchow. Proc. XIthint. Wld. Vet. Asso., Budapest, Hungary, PP.192. fliirirpct Ty $n_{\prime}, 1(Y)$

8. Michael,A., B. Guter, M. Barbakov, G. Galili, J. Pitkovki, T. Maarry and H. Yahuda. 1997. Development of inectious bursal disease (IBD) vaccine of intermediate invasevness from a very virulent (vv) IBD virus. Proc.XIth Int.Cong.Wld.Vet.Assoc. Budapest. Hungary. Pp 185.

9. Nadia.M.Ibrahim. 2001. Comparative studies on infectious bursal disease virus vaccine in broilers chickens. Thesis, Ph.D. (virology), Fac. Vet. Med., Cairo University (Beni-Suef Branch).

10. Nakamura,K., H. Yuasa and M. Narita. 1990. Effect of bursal disease virus on infections produced by E. coli of high and low virulence in chickens.Avi. Path., 19: 713-72 1. 
11. Nieper,H. and H. Muller. 1994. Attempts to define hot cell permissiveness of IBDV by cell receptors. Int.Symp. on infectious bursal disease virus and chicken infectious aaemia, Rauischholzhausen.

12. Rao,S. U.M., B. Sambamurti and B.B. Mallick. 1978. Dwarfing and mortality of chicken embryos caused by indigenous isolates of infectious bursal disease virus. Indian J.Anim.HIth, 17:111-114.

13. Reed, L.J. and H. Muench. 1938. A simple method of estimating fifty percent end points. Amr.J.Hyg., 27: 493.

14. Rinaldi,A., D. Cessi, G. Cervico and E. Lodetti. 1972.Attenuation of Gumboro disease virus and vaccination trials under field conditions. Nuova Vet., 48 (4): 216223.

15. Rossiter, P.B., D.M. Jessett and W.P. Taylor. 1985. Microneutralization system for use with different strains of paste des petits ruminams virus and rinder pest virus. Trop. Anim.HIth.Prod., 17 (2): 75-81.

16. Saif, Y.M. 1994.Antigenicity and Immunogenicity of infectious bursal disease virus. 4th Symp. WLd. Vet. Poult. Asso., pp.37-39.

17. Saif-Edin, M., M.Aly and S. Mousa. 1996.Status of infectious bursal disease in Egypt. I-Nature of last severe outbreaks. Proc. 4th Sci. Conf. Egypt.Vet. Poult Asso., 65-81.

18. Tsai,H.J. and Y.M. Saif. 1992.Effect of cell culture passage on the pathogenicity and immunogenicity of two variant strains of infectios bursal disease virus. Avi. Dis., 36: 4 I 5-422.

19. Tsukamoto,k., N. Tanimura, M. Mose and K. Jmai. 1995. Comparison of virus replication efficiency in lymphoid tissues among three infectious bursal disease virus strains. Avi. Dis., 39: 844-852.

20. Yamaguchi, I., K. Iwata, M. Kobayasshi, M. Ogawa, H. Fukashi and K. Hirari. 1996. Epitope mapping of capsid proteins VP2 and VP3 of infectious bursal disease virus.Arch.Virol., 141: 1493-I 507. 
دراسة القدره المناعية للعترة المعزولة محيا" لفيروس التهاب غدة فابريشيس بعد تمريرها علي آجنة البيض الخالي من المسببات المرضية

نادية محمد إبر اهيم

معهُ بحوث الأمصال و اللقاحات البيطرية - العباسية - مركز البحوث النرراعية - وزلرة الزراعة

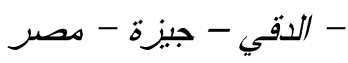

تم تمرير العترة المعزولة محليا " من فيروس مرض التهاب غده فابريشبس ب تمرير ات علي

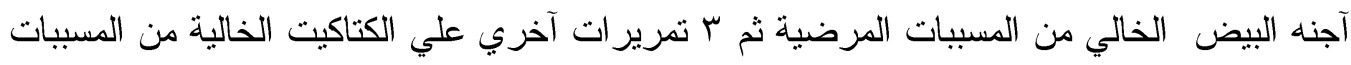
المرضية ثم مائة و عشرة ( • (1) تمريرة علي آجنة البيض الخالي من المسببات المرضية و قد تم

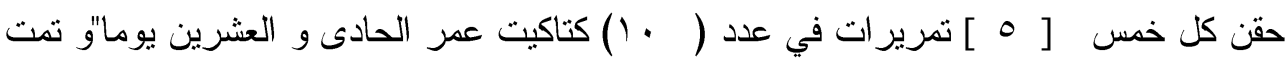

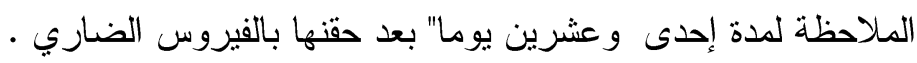

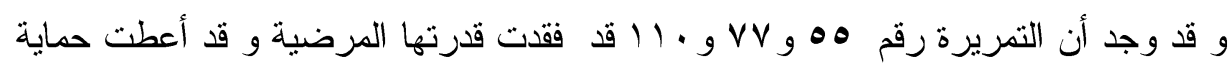
للكتاكيت المحقونة بنسبة . 1 \% و استخدمت لتحضير لقاح حي مستضعف لفيروس مرض التهاب غده فابريشبس . و قد تم تقييم اللقاح المحضر من حيث النقاوة و الآمان و القدرة المناعية و قد تم قياس

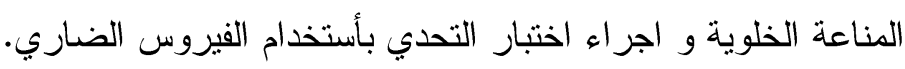

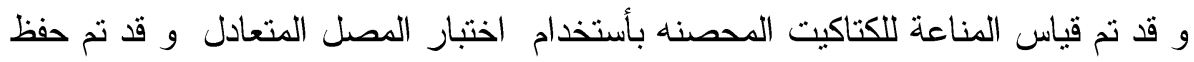

اللقاح عند - • به م لمدة ستة شهور متتالية و قد ثم اختبار قوة الصد في الكتاكيت المحصنة.

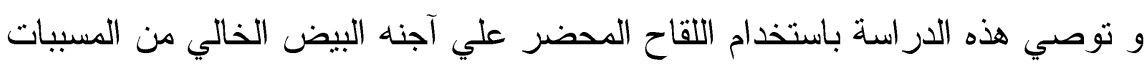

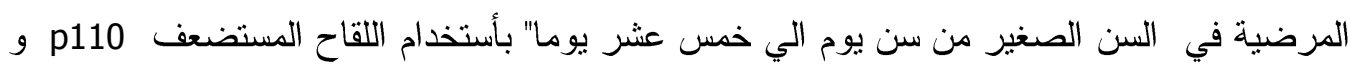

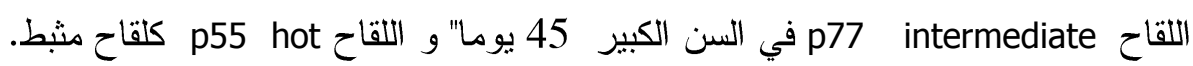

